Scientific journal

PHYSICAL AND MATHEMATICAL EDUCATION

Has been issued since 2013.

Науковий журнал

ФІЗИКО-МАТЕМАТИЧНА ОСВІТА

Видається з 2013.
ISSN 2413-158X (online)

ISSN 2413-1571 (print)

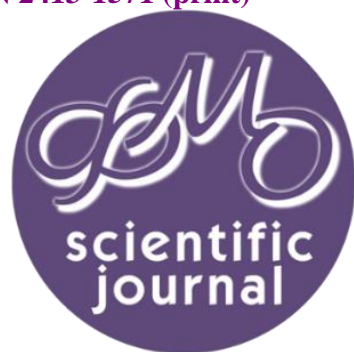

Кудін А.П. Організація самостійної роботи студентів на базі симуляційного лабораторного практикуму з основ цифрової електроніки. Фізико-математична освіта. 2021. Випуск 4(30). С. 61-67.

Kudin A. Organization of the independent work of students with help of a simulation laboratory workshop on the basics of digital electronics. Physical and Mathematical Education. 2021. Issue 4(30). P. 61-67.

DOI 10.31110/2413-1571-2021-030-4-009

Удк 378.146

А.П. Кудін

Національний педагогічний університет імені М.П. Драгоманова, Україна

kudin@npu.edu.ua

ORCID: https://orcid.org/0000-0001-6907-644X

\title{
ОРГАНІЗАЦІЯ САМОСТІЙНОї РОБОТИ СТУДЕНТІВ НА БАЗІ СИМУЛЯЦІЙНОГО ЛАБОРАТОРНОГО ПРАКТИКУМУ З ОСНОВ ЦИФРОВОЇ ЕЛЕКТРОНІКИ
}

АНОТАЦІЯ

Формулювання проблеми. «Фізика (вибрані розділи)» $є$ нормативною дисципліною навчальних планів спеціальностей 121,122 і 126 галузі знань “Інформаційні технології» і вивчає фізичні основи роботи пристроїв цифрової електроніки в комп'ютері. Використання інформаційних технологій в організації і забезпеченні самостійної роботи студентів призвели до появи у ЗВО такого різновиду лабораторного практикуму як симуляційний. Аналіз існуючих в інтернеті симуляційних лабораторних практикумів показав, що вони не відповідають змісту вказаної вище дисципліни.

Метою дослідження $\epsilon$ розробка віртуального симуляційного лабораторного практикуму "Основи цифрової електроніки» $і$ організація самостійної роботи студентів спеціальностей 121, 122 і 126 на його основі.

Методи та інструменти. Компонентами фронтенд розробки були HTML5, CSS, Java Script та C\#. Для бекенда - фреймворки Laravel, Node.js i Django, як мова програмування Pуthon. Основною методикою педагогічного дослідження було мережеве тестування. Статистичні дані були отримані із тестуючого модуля LMS MOODLE.

Результати. Лабораторний практикум складається з 18 симуляційних лабораторних робіт. В основу проєктування інтерфейсу освітніх симуляцій покладено важливий дидактичний принцип: відповідати за навчальні потреби студентів. Усі симуляції анімовані, інтерактивні, деякі мають ігрові середовища, в яких можна вивчати роботу пристроїв через дослідження. Показано, якими проєктними рішеннями досягається оптимальний людино-машинний інтерфейс освітніх симуляцій в лабораторному практикумі. у статті описано сценарій організації самостійної роботи студентів з дисципліни «Фізика (вибрані розділи)» на базі розробленого лабораторного практикуму з використанням засобів комунікацій LMS MOODLE.

Висновки. Використання симуляційного лабораторного практикуму "Основи цифрової електроніки» в організації самостійного навчання сприяє підвищенню мотивачії студентів до вивчення курсу "Фізика (вибрані розділи)». Подальщого дослідження потребує питання розробки і використання навчальних ігор для самоосвіти студентів.

ключовІ словА: лабораторний практикум, цифрова електроніка, симуляція, самостійна робота.

\section{ВСТУП}

Необхідність пошуку нових підходів щодо організації самостійної роботи студентів у сучасних умовах (дистанційне, змішане навчання) пов'язана з розв'язанням головної проблеми віддаленого навчання - формуванням у студентів мотиваційних чинників до самоосвіти. Психологи (Гилюн,2012) стверджують, що в навчанні мотив у 3 рази важливіший за інтелект, мотивація - це спонукання людини до скоєння усвідомлених або неусвідомлених дій. Вплинути на виконання студентом усвідомлених дій у сфері самоосвіти за умови віддаленого навчання практично неможливо. Це пояснюється уже сформованими особистісними рисами характеру (цілеспрямованістю, наполегливістю) студента. А от спонукати до скоєння неусвідомлених дій під час самоосвіти можна, використовуючи діяльнісний особистісно-орієнтований диференційований підхід у навчанні. В сучасних умовах реалізація цього підходу відбувається в процесі людино-машинної взаємодії, яка побудована на особливостях людського сприйняття, мислення й пам'яті.

Найбільший відсоток у сприйнятті (до 80\%) і запам'ятовуванні (до 50\%) інформації (Вітенко, 2008) мають мультимедійні інтерактивні засоби навчання, в яких інформація представлена у вигляді тексту, відео, анімації, звуку, моушендизайну. Такими є симуляційні моделі. Симуляція забезпечує навчання дією (Манюкова\&Никонова, 2017) 
Оскільки комп'ютерні симуляції, як правило, використовують в процесі індивідуальної роботи, студенти мають можливість працювати в зручному для них темпі, зупиняючись на складних етапах і домагаючись повного розуміння суті досліджуваного процесу, що важливо при самоосвіті.

Гіпотеза даного дослідження: для підвищення мотивації у студентів до навчання за дистанційними технологіями необхідно розробити інтерактивні засоби навчання з високими показниками сприйняття інформації, до яких належить симуляційний лабораторний практикум.

Необхідно відзначити, що розробка симуляційних моделей навчального призначення набула бурхливого розвитку впродовж останніх 5-и років у зв' язку з переходом освіти України на використання дистанційних технологій у навчальному процесі, складовою якого є лабораторні заняття.

Аналіз літературних джерел. Як відомо, освітня симуляційна модель імітує реальні ситуації для навчання або отримання оцінки виконаної роботи. В основі освітньої симуляції лежить спеціально розроблений сценарій зі своєю системою навчальних правил і завдань, метою якого $є$ формування компетенцій, необхідних для успішної діяльності в реальній дійсності. Першими, хто зацікавився таким засобом навчання, були медичні освітні заклади, які і зараз $є$ лідерами в їх розробці. Так, у 2019 році на базі програмного продукту «Апарат штучного кровообігу SORIN C5» авторами Л.Суховірською та ін. був розроблений цикл симуляційних лабораторних робіт з біофізики для медиків (Суховірська, 2019).

Авторами С. Мисловською, К. Добровольською, В. Ревенок на першій міжнародній науково-практичній конференції «SCIENCE. INNOVATION. QUALITY - 2020» був представлений лабораторний практикум з дисципліни «Медична і біологічна фізика» для навчання студентів-медиків (Мисловська\&Добровольська\&Ревенок, 2020). Підвищений інтерес до цього виду інтерактивних засобів у медичній освіті обумовлений можливістю «зробити помилку у діях лікаря без наслідків».

Можливість експериментувати в симуляції, не турбуючись про наслідки, спонукає економічні університети і бізнесшколи до розробки і впровадження в навчальний процес комп'ютерних симуляцій (Кравчук \&Шевчук, 2019).

У зв'язку з пандемією Covid-19 активізувались розробники інтернет-платформ із симуляційними дослідами для шкільного курсу фізики, з якими можна ознайомитись на сайті (www.naurok.com.ua, 2021). Серед них виділяється високим рівнем виконання фронтенду розробка університету з штату Колорадо (симуляції PhET).

Особливо цікавим виглядає проєкт із залучення студентів до створення відкритого банку фізичних симуляцій для ЗВО України (www. simpop.org , 2021).

Зміст дисципліни «Фізика (вибрані розділи)», яка входить до обов'язкового компоненту освітніх програм циклу загальної підготовки трьох спеціальностей галузі знань 12 «ннформаційні технології» (121 «ннженерія програмного забезпечення», 122 «Комп'ютерні науки», 126 «Інформаційні системи та технології»), складають питання вивчення фізичних основ роботи елементів цифрової електроніки. Аналіз існуючих в інтернеті університетських симуляційних практикумів (www.sunspire.ru/products/physics2d; www.virtulab.net; www.mospolytech.ru/science, 2021; Веселова\&Штейн, 2017; Мамулуй, 2013) показав, що вони розроблені для вивчення вибраних питань курсу «Загальної фізики», які не відповідають програмі вищезгаданої дисципліни.

Крім того, згідно із сучасними вимогами, у навчальних планах спеціальностей 121, 122 і 126 галузі знань «Інформаційні технології» на вивчення дисципліни «Фізика (вибрані розділи)» 6 кредити, з них 1,2 на лабораторнопрактичні заняття і 2,3 на самостійну роботу, яка на інженерних спеціальностях має носити виключно практичний характер. Тому для забезпечення лабораторно-практичної частини навчального плану була поставлена мета - розробити віртуальний симуляційний лабораторний практикум “Основи цифрової електроніки» і на його базі удосконалити організацію самостійної роботи студентів трьох спеціальностей.

\section{МАТЕРІАЛИ І МЕТОДИ}

Компонентами фронтенд-розробки були HTML5, CSS i Java Script. Іноді використовувалася мова С\#. Для бекенда фреймворки Laravel, Node.js і Django, як мова програмування Python.

Педагогічним експериментом були охоплені студенти факультету інформатики трьох спеціальностей 121 «Інженерія програмного забезпечення» (82 особи), 122 «Комп'ютерні науки» (30) і 126 «Інформаційні системи і технології» (12). Основними методами дослідження були мережеве комп'ютерне тестування, статистичні методи обрахунку та письмове анкетування. Статистичні дані були отримані із тестуючого модуля LMS MOODLE.

\section{РЕЗУЛЬТАТИ ТА ОБГОВОРЕННЯ}

Середовищем для організації самостійної роботи була вибрана LMS MOODLE, тому лабораторний практикум 3 симуляціями - «Віртуальна лабораторія фізичних дослідів» був розміщений у ній (https://moodle.fi.npu.edu.ua/course/view.php?id=391). Там же знаходились усі інструкції до 18-и лабораторних робіт (Таблиця 1.). Усі виготовлені симуляції $€$ сайтами з відкритим кодом. Симуляції анімовані, інтерактивні, деякі мають ігрові середовища.

Усі симуляційні роботи поділяються на «без експериментальної установки» (№1-№3, №18) i «3 експериментальною установкою» (№4 - №17). У першому типі робіт завдання студента полягає у візуальному спостереженні на екрані (без письмового фіксування, без керування приладами) налаштованих симуляцій показів приладів.

Проєктування інтерфейсу навчальної симуляції.

В основу проєктування інтерфейсу навчальної симуляції покладений важливий принцип сучасної дидактики: інтерфейс навчального засобу повинен відповідати тільки навчальним потребам студентів.

Які це потреби? 


\begin{tabular}{|c|c|c|}
\hline \multicolumn{3}{|r|}{ Список лабораторних робіт } \\
\hline № & Назва & Що можна \\
\hline 1 & $\begin{array}{l}\text { Електронна структура кристалу } \\
\text { германію }\end{array}$ & $\begin{array}{l}\text { Спостерігати окремо різні типи власної провідності чистого германію. } \\
\text { Змінюючи температуру, спостерігати зміни рухів атомів ґратки. }\end{array}$ \\
\hline 2 & Домішкова провідність & $\begin{array}{l}\text { Спостерігати модель утворення ковалентного зв'язку у Ge і два типи } \\
\text { домішкової провідності. }\end{array}$ \\
\hline 3 & Утворення п-р-переходу & $\begin{array}{l}\text { Спостерігати явища, які відбуваються у ґратках Ge n-типу i Ge p-типу } \\
\text { при з'єднанні двох напівпровідників в приконтактній області. }\end{array}$ \\
\hline 4 & $\begin{array}{l}\text { Дослідження різних типів включення } \\
\text { п-р-переходу: пряме і зворотне }\end{array}$ & $\begin{array}{l}\text { Змінювати вхідну напругу і спостерігати за змінами характеристик } \\
\text { приконтактної області, отримати ВАХ }\end{array}$ \\
\hline 5 & $\begin{array}{l}\text { Однонапівперіодне випрямлення } \\
\text { змінного електричного струму на діоді }\end{array}$ & $\begin{array}{l}\text { Змінюючи вхідну напругу, спостерігати випрямлення змінного струму } \\
\text { діодом. }\end{array}$ \\
\hline 6 & $\begin{array}{l}\text { Двонапівперіодне випрямлення } \\
\text { змінного електричного струму на діоді }\end{array}$ & $\begin{array}{l}\text { Змінюючи вхідну змінну напругу, спостерігати випрямлення } 3 \\
\text { допомогою моста з } 4 \text { діодах. }\end{array}$ \\
\hline 7 & $\begin{array}{l}\text { Інтерактивна демонстрація роботи } \\
\text { варікапа на діоді }\end{array}$ & $\begin{array}{l}\text { Змінюючи вхідну напругу, спостерігати явища в приконтактній зоні n-p- } \\
\text { переходу, зміни сили струму, ширини і ємності n-р-переходу. }\end{array}$ \\
\hline 8 & $\begin{array}{l}\text { рактивна демонстрація роботи } \\
\text { одіода }\end{array}$ & $\begin{array}{l}\text { Отримали вольтамперну характеристику запірного включення діода } \\
\text { при різних типах освітлення. }\end{array}$ \\
\hline 9 & $\begin{array}{l}\text { Польовий транзистор з ізольованим } \\
\text { затвором }\end{array}$ & $\begin{array}{l}\text { Провести три досліди; отримати залежність струму у колі СТОК-БАЗА } \\
\text { від напруги у колі БАЗА-ВИТОК. }\end{array}$ \\
\hline 10 & $\begin{array}{l}\text { Польовий транзистор з плаваючим } \\
\text { затвором }\end{array}$ & $\begin{array}{l}\text { Зафіксувати напругу на ЗАТВОРІ, коли електрони із каналу «тунелюють» } \\
\text { в плаваючий ЗАТВОР. }\end{array}$ \\
\hline 11 & $\begin{array}{l}\text { Польовий транзистор з керованим } \\
\text { п-р-переходом }\end{array}$ & Отримати ВАХ транзистора \\
\hline 12 & Біполярний транзистор & Отримати BAX транзистора; спостерігати демонстрацію роботи ключа. \\
\hline 13 & $\begin{array}{l}\text { Дослідження магнітного гістерезису у } \\
\text { феромагнетиках }\end{array}$ & $\begin{array}{l}\text { Побудувати по експериментальних точках петлю магнітного } \\
\text { гістерезису феромагнетика. Спостерігати перебудови структури } \\
\text { доменів. }\end{array}$ \\
\hline 14 & $\begin{array}{l}\text { Симулятор роботи комірки пам'яті } \\
\text { DRAM }\end{array}$ & $\begin{array}{l}\text { Змінюючи вхідну напругу, спостерігати явище діелектричного } \\
\text { гістерезису та процеси перебудови структури у комірці пам'яті. }\end{array}$ \\
\hline 15 & $\begin{array}{l}\text { Симулятор роботи комірки пам'яті } \\
\text { SRAM }\end{array}$ & $\begin{array}{l}\text { Спостерігати процес програмування та перепрограмування логічного } \\
\text { «0» i «1» у тригері SR - ефект пам'яті }\end{array}$ \\
\hline 16 & $\begin{array}{l}\text { Симулятор роботи системи } \\
\text { охолодження ноутбука }\end{array}$ & $\begin{array}{l}\text { Спостерігати явища, що відбування в трубках системи охолодження } \\
\text { при роботі процесора і кулера. }\end{array}$ \\
\hline 17 & $\begin{array}{l}\text { Симулятор «ефект Фредеріксена» у } \\
\text { LED }\end{array}$ & $\begin{array}{l}\text { Спостерігати явище поляризації світла, явище керування площиною } \\
\text { поляризації за допомогою зміни напруги на рідкому кристалі }\end{array}$ \\
\hline 18 & $\begin{array}{l}\text { Симуляційна 3D-модель внутрішнього } \\
\text { структури сегнетоелектрика }\end{array}$ & $\begin{array}{l}\text { Спостерігати вплив: температури на утворення диполя в елементарній } \\
\text { комірці сегнетоелектрика; зовнішнього електричного поля на } \\
\text { перебудову атомів в елементарній комірці сегнетоелектрика і на } \\
\text { доменну структуру сегнетоелектрика. }\end{array}$ \\
\hline
\end{tabular}

1.Наявність програм для вирішення тільки своїх завдань, при цьому головним є зручність і потрібний результат. Тому на екрані освітній інтерфейс виглядає мінімалістично. Тільки те, що студентові необхідно: експериментальна установка, екран мікроскопа, кнопки керування вхідної напруги і у вікні, що випливає, теоретичне пояснення баченого.

Зручною для навчання симуляція буде тоді, коли навігаційна схема має лише кілька переходів, які треба зробити користувачеві в рамках одного сценарію. Тому в лабораторному практикумі використовували до 5 закладок різних екранів. Кожен екран має оптимально скомпоновану кількість функцій: у більшості лабораторних їх не більше 4.

Блоки одного типу розміщені на різних екранах в одному місці: наприклад, блок кнопок для керування вхідною характеристикою розташовано ліворуч, а блок пристроїв вихідного сигналу - праворуч. Блок екранів мікроскопів - під експериментальною установкою. Блок додаткової інформації - справа зверху у вікні, що випливає.

2. Готовність студента розуміти запропонований інтерфейс. Часто розробники програмного забезпечення ділять користувачів за групами: непідготовлений користувач, комп'ютерно-освічений і просунутий. У випадку освітнього симулятора такого не повинно бути: незалежно від того, наскільки складною є задача, що розв'язується, складові частини цієї задачі однаково повинні бути простими і пізнаваними. Тому для кнопок, графіків використовувались традиційні позначення і форми.

3. Логістика сценарію, яка задається структурою інтерфейсу: кількістю і призначенням екранних форм, встановлення зв'язку між формами. Так, у лабораторній роботі №9 «Польовий транзистор з ізольованим затвором» інтерфейс складається з трьох екранних форм (слайдів) (рис.1). На першому і другому слайді показана експериментальна установка без «затвору» з підключенням до "стоку» різної полярності батареї; на третьому слайді експериментальна установка із затвором, стоком і витоком. Така послідовність дозволяє зрозуміти, що незалежно від напрямку підключення батареї до стоку струму не буде; струм з'являється тільки в тому випадку, коли на затвор підключена «+» полярність додаткового керуючого джерела напруги. 
4. Динамічні об'єкти (моушен). Як засвідчують психологи, рухомі об'єкти привертають більшу увагу, тому в експериментальних установках анімований електричний струм, зміна розмірів певних зон і т.п. (рис.2).

5. Спонукання до дій. На екрані розміщені закладки, повзунки, кнопки, іконки, вікна, що спливають - активні елементи інтерфейсу, які спонукають до дій. Ознакою хорошого інтерфейсу є відчуття в користувача, що саме він керує програмним забезпеченням, а не програмне забезпечення керує ним.
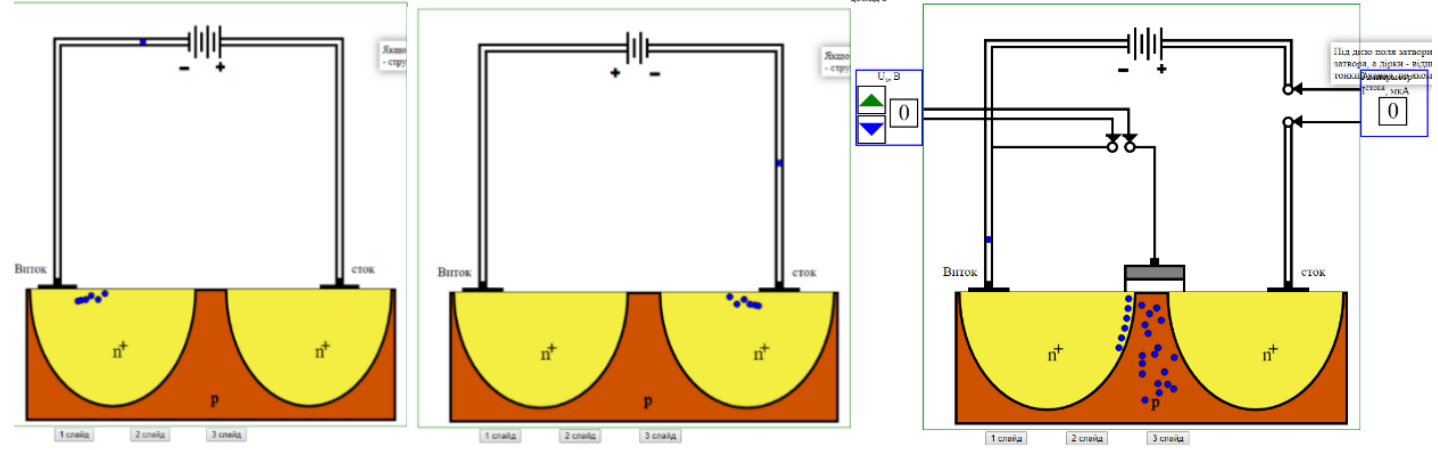

Рис. 1. Демонстрація зв'язку між екранними формами в лабораторній роботі №9

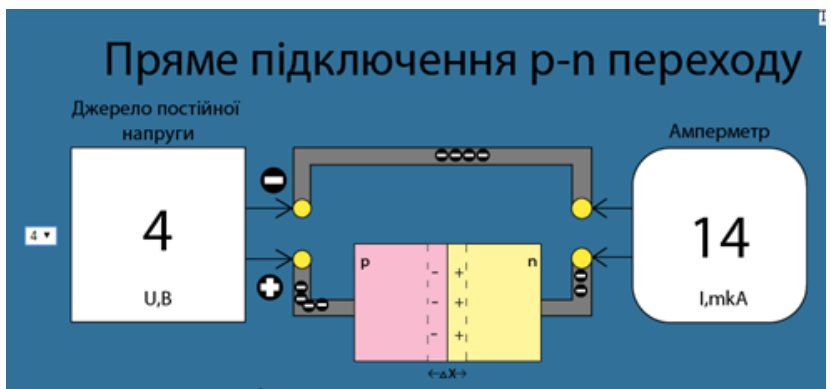

Рис. 2. Лабораторна робота №4. «Дослідження різних типів включення п-р-переходу». Спостереження за рухом електронів і розмірами зони збідненої на носії зарядів $\Delta x$.

Так, в лабораторній роботі №18 «Симуляційна 3D-модель внутрішньої структури сегнетоелектрика» (рис.3) для задання напрямних косинусів при різних напрямках дії зовнішнього електричного поля передбачені повзунки та екран (знизу ліворуч) з демонстрацією напрямних ортів декартової системи координат.

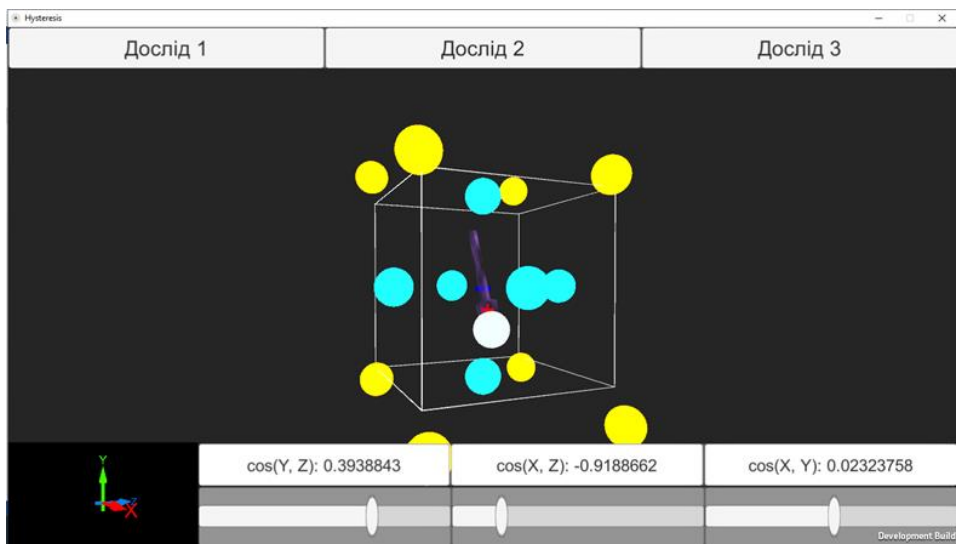

Рис. 3. Закладка «Дослід 2» з лабораторної роботи №18. Спостереження явища поляризації (відносне зміщення атомів) елементарної комірки кристалічної гратки ВаTіO4.

6. Можливість спостерігати за тим, що неможливо зафіксувати без спеціальної апаратури. Наприклад, (на рис.4) зміни в доменній структурі кристалу під час накладання силових ліній магнітної індукції у вікні мікроскопа (знизу ліворуч), характер розповсюдження ліній магнітної індукції навколо соленоїда (навколо котушки), модель руху електричних зарядів по провіднику, ефект Холла у напівпровідниковому кристалі в формі паралепіпеда (зверху).

7. Зняття показів приладів і їх обробка на основі формул як навчальна задача традиційного лабораторного практикуму. Симуляційна лабораторна робота має традиційну частину фізичного експерименту: в інструкції до лабораторної роботи є формули, на основі яких проводиться обрахунок експериментально отриманих даних.

\section{Організація самостійної робити студентів.}

Налаштування доступу студентів до певних лабораторних робіт може бути встановлено згідно з графіком навчального процесу. Отримавши завдання виконати відповідну кількість лабораторних робіт, студент спочатку 
завантажує інструкцію до виконання лабораторної роботи з курсу в LMS MOODLE за посилання «Інструкція до ЛП-роботи». Прочитавши їі, ознайомлюється з симуляційною установкою за посиланням «Віртуальна лабораторія фізичних дослідів».

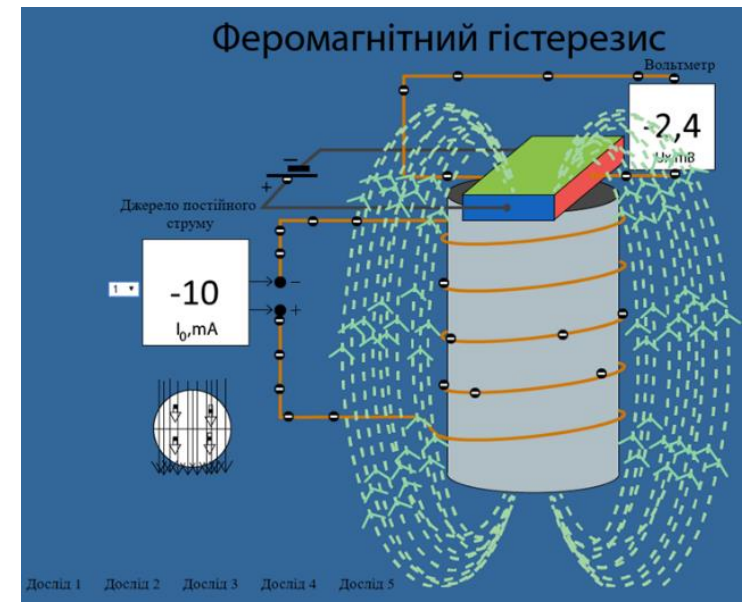

Рис. 4. Лабораторна робота №13: відображено анімацією рух електронів у трьох електричних колах, розповсюдження ліній індукції магнітного поля і орієнтації доменів під мікроскопом в магнітному полі

Після цього проходить допуск до лабораторної роботи, складаючи відповідний тест у модулі тестування LMS MOODLE. Склавши успішно, може приступати до виконання лабораторного експерименту на симуляційній установці. Виконавши всі завдання з інструкції до лабораторної роботи, він складає протокол виконання лабораторної роботи, який відправляє викладачеві і складає контрольний тест в LMS MOODLE. Завдяки модулю статистики у LMS MOODLE, викладач може отримати дані про час роботи студента на сайті «Віртуальна лабораторія фізичних дослідів», а також результати тестування: допуск і контрольний тест.

\section{Педагогічний експеримент}

Досліджувавався параметр, який може свідчити про вмотивованість студентів вивчати фізику на базі симуляційного лабораторного практикуму - це кількість комунікацій між учасниками навчального процесу. У програмній оболонці MOODLE для його фіксації можна використати сервіс «чат», який дозволяє комунікувавтися всім учасникам навчального процесу. У навчальному процесі студенти користуються ним, як правило, для обговорення матеріалів електронного курсу і домашнього завдання, а також для спілкування з викладачем. В оболонці MOODLE $\epsilon$ можливість робити підрахунок повідомлень - комунікацій, відправлених через сервіс «чат». На рис. 5 показана кількість зафіксованих в оболонці курсу комунікацій між студентами однієї групи протягом 19 тижнів (семестр).

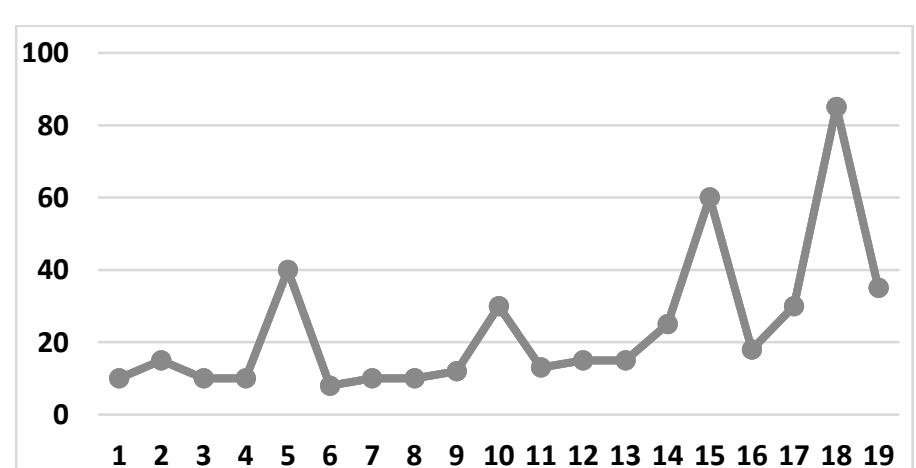

Рис. 5. Щотижнева кількість комунікацій, які зафіксовані в електронному курсі, між студентами протягом 19 тижнів 20/21 навчального року

Видно, що в окремі дні місяця активність спілкування зростала. Щоб зрозуміти, з чим це пов'язано, достатньо подивитись на дидактичну карту курсу. Встановлено, що «спалахи» спілкування припадають на тижні, коли проходили лабораторно-практичні заняття на базі симуляційного лабораторного практикуму: це 5,10,15,18 тижні семестру. Якщо проаналізвати зміни даних за чотири місяці, то видно, що ордината максимумів «спалахів» комунікацій зростає, тобто кількість комунікацій протягом семестру збільшується. Отже, використання у навчанні симуляційного лабораторного практикуму приводить до зростання позаудиторного групового спілкування між учасниками навчального процесу 3 питань навчального характеру.

\section{висновки}

Розроблений симуляційний лабораторний практикум «Основи цифрової електроніки» повністю забезпечує викладання лабораторно-практичної частини навчальної програми вказаної дисципліни: спостерігати, які фізичні процеси і явища лежать в основі роботи пристроїв комп'ютера. 
Дані педагогічного експерименту показали, що використання симуляційного лабораторного практикуму «Основи цифрової електроніки» в організації самостійного навчання сприяє підвищенню мотивації студентів до вивчення курсу «Фізика (вибрані розділи)». Включення студентів в інтерактивні технології навчання із продуктивною самостійною діяльністю дозволяють істотно підвищити рівень професійної підготовки майбутнього фахівця в ІТ-галузі.

Розроблені віртуальні симуляції можуть використовувались як для організації самостійної роботи студентів, так $\mathrm{i}$ для демонстрації викладачем динамічних рисунків на сенсорних дошках під час аудиторних теоретичних і фронтальних лабораторних занять. Подальшого дослідження потребує вивчення питання розробки і використання навчальних ігор на базі симуляцій для самоосвіти студентів.

\section{Список використаних джерел}

1. Веселова С.В., Штейн Б.М. Дистанционное обучение: лабораторный практикум по физике: дома и на природе. Международный научный журнал «Мир науки, культуры, образования». 2017. № 1 (62). С. 187-191.

2. Використання симуляцій при викладанні нового матеріалу URL: https://naurok.com.ua/vikoristannya-simulyaci-privikladanni-novogo-materialu-rozv-yazuvanni-zadach-ta-provedenni-laboratornih-robit-z-fiziki-206501.html (Дата звернення 2.06.2021).

3. Вітенко І.С., Вітенко Т.І. Основи психології. Видання друге, перероблене і доповнене /І.С. Вітенко, Т.І. Вітенко. Вінниця: НОВА КНИГА, 2008. 256 с.

4. Гилюн О. В. Освітні мотивації студентської молоді. Грані: наук.- теорет. і громад.-політ. альманах / Дніпропетровський нац. ун-т ім. О. Гончара;. Д., Центр соц.-політ. дослідж. 2012. - № 1 (81). - С. 102-104.

5. Загальна фізика. Лабораторний практикум: навч. посіб. Квантова механіка. Фізика атомів і молекул. Фізика твердого тіла. Фізика атомного ядра та елементарних частинок / А. О. Мамалуй та ін.; за заг. ред. А. О. Мамалуя Харків, Ч. 3. 2013. 172 c.

6. Колтунов И.И., Акимов А.В., Липай Б.Р. Лабораторные работы для дистанционного обучения студентов: Материалы 77-й международной научно-технической конференцыии ААИ «Автомобиле-и тракторостроение в России: приоритеты развития и подготовка кадров» URL: http://mospolytech.ru/science/aai77/scientific/article/s14/s14_11.pdf (Дата звернення: 30.11.2020).

7. Кравчук Г.Т., Шевчук Т.В. Симуляція як інтерактивний метод навчання майбутніх фахівців-економістів. Фізикоматематична освіта. 2019. Випуск 2(20). С. 59-65.

8. Манюкова Н.В., Никонова Е.3. Организация интерактивного обучения с помощью MS EXCEL в качестве инструмента компьютерной симуляции. Современные исследования социальных проблем, 2017. Том 8, № 4. С.101-112.

9. Мисловська С., Добровольська К., Ревенок В. laboratory workshop on the subject "Medical and Biological Physics" for teaching medical student. Science. Innovation. Quality: 1st International Scientific-Practical Conference SIQ (SCIENCE. INNOVATION. QUALITY)- 2020, December 17-18th, 2020: Book of Papers. - Berdyansk : BSPU, 2020. C.49-50.

10. Сайт.Віртуальна лабораторія загальної фізики ЗВО URL: https://www.sunspire.ru/products/physics2d/(Дата звернення 2.06.2021).

11. Сайт.Віртуальна освітня лабораторія VirtuLab/ URL:http://www.virtulab.net/index.php?option=com_ content\&view =section\&layout=blog\&id=5\&ltemid=94/ (Дата звернення 2.06.2021).

12. Сайт SimPop: Симулятори фізики та ігри. URL: https://simpop.org/physics.htm (Дата звернення 2.06.2021).

13. Суховірська Л.П. та ін. Система віртуальних лабораторних робіт з біофізики як засоби реалізації принципу професійної спрямованості навчання студентів . Інформаційні технології і засоби навчання, 2019, Том 70, №2, С.141-151.

\section{References}

1. Veselova S.V.\& Shtejn B.M. (2017). Distancionnoe obuchenie: laboratornyj praktikum po fizike: doma i na prirode. Mezhdunarodnyj nauchnyj zhurnal «Mir nauki, kul'tury, obrazovanija». 1 (62), 187-191. [in Russian].

2. Vykorystannia symuliatsii pry vykladanni novoho materialu. Retrieved from https://naurok.com.ua/vikoristannya-simulyacipri-vikladanni-novogo-materialu-rozv-yazuvanni-zadach-ta-provedenni-laboratornih-robit-z-fiziki-206501.html] [in Ukrainian].

3. Vitenko I.S. \& Vitenko T.I. (2008) Osnovy psykholohii. [Vydannia druhe, pereroblene i dopovnene /I.S. Vitenko, T.I. Vitenko]. - Vinnytsia: NOVA KNYHA. [in Ukrainian].

4. Hyliun O. V. (2012) Osvitni motyvatsii studentskoi molodi. Hrani : nauk.- teoret. i hromad.-polit. almanakh / Dnipropetrovskyi nats. un-t im. O. Honchara;. D., Tsentr sots.-polit. Doslidzh. 1 (81),102-104. [in Ukrainian]

5. Mamalui O.A. et al (2013) Zahalna fizyka. Laboratornyi praktykum : navch. posib. Kvantova mekhanika. Fizyka atomiv $i$ molekul. Fizyka tverdoho tila. Fizyka atomnoho yadra ta elementarnykh chastynok. Kharkiv: 3. [in Ukrainian].

6. Koltunov I.I.\& Akimov A.V.\& Lipaj B.R. Laboratornye raboty dlja distancionnogo obuchenija studentov. [Materialy 77-j mezhdunarodnoj nauchno-tehnicheskoj konferencyii AAl «Avtomobile-i traktorostroenie v Rossii: prioritety razvitija $\mathrm{i}$ podgotovka kadrov»] Retrieved from http://mospolytech.ru/science/aai77/scientific/article/s14/s14_11.pdf. [in Russian].

7. Kravchuk H.T. \& Shevchuk T.V. (2019) Symuliatsiia yak interaktyvnyi metod navchannia maibutnikh fakhivtsiv-ekonomistiv. Fizyko-matematychna osvita. 2(20), 59-65. [in Ukrainian].

8. Manjukova N.V. \& Nikonova E.Z. (2017) Organizacija interaktivnogo obuchenija s pomoshh'ju MS EXCEL v kachestve instrumenta komp'juternoj simuljacii. Sovremennye issledovanija social'nyh problem, 8 (4), 101-112. [in Russian].

9. Myslovska S. \& Dobrovolska K. \& Revenok V. (2020) laboratory workshop on the subject "Medical and Biological Physics" for teaching medical student. Science. Innovation. Quality: 1st International Scientific-Practical Conference SIQ (SCIENCE. INNOVATION. QUALITY)- 2020, December 17-18th, 2020: Book of Papers. - Berdyansk : BSPU, 49-50.

10. Sait.Virtualna laboratoriia zahalnoi fizyky ZVO. Retrieved from https://www.sunspire.ru/products/physics2d /[in Ukrainian]. 
11. Sait.Virtualna osvitnia laboratoriia VirtuLab. Retrieved from http://www.virtulab.net/index.php ?option =com_content\&view =section\&layout=blog\&id=5\&ltemid=94/ [in Ukrainian]

12. Sait SimPop: Symuliatory fizyky ta ihry. Retrieved from https://simpop.org/physics.html [in Ukrainian].

13. Sukhovirska L.P. (2019) Systema virtualnykh laboratornykh robit z biofizyky yak zasoby realizatsii pryntsypu profesiinoi spriamovanosti navchannia studentiv . Informatsiini tekhnolohii i zasoby navchannia, 70 (2), 141-151. [in Ukrainian].

\section{ORGANIZATION OF THE INDEPENDENT WORK OF STUDENTS WITH HELP OF A SIMULATION LABORATORY WORKSHOP ON THE BASICS OF DIGITAL ELECTRONICS}

\section{A.P. Kudin}

Drahomanov National Pedagogical University, Ukraine

Abstract.

Formulation Problem. "Physics (selected sections)" is a normative discipline of the curricula of specialties 121, 122 and 126 in the field of knowledge "Information Technology" and studies the physical foundations of digital electronics in computers. Providing information technology in the organization of independent work became a reason of developing a simulation laboratory workshop. An analysis of the existing simulation laboratory workshops on the Internet showed that they do not correspond to the content of the discipline.

The aim of studying of the development of a virtual simulation laboratory workshop "Fundamentals of Digital Electronics" and the organization of independent work of students specialty 121, 122 and 126 on its basis.

Methods and tools. The frontend development components were HTML5, CSS, JavaScript, and C \#. For the backend - Laravel, Node.js, and Django frameworks, as a Python programming language. The main method of pedagogical research was network testing. Statistics were obtained from the LMS MOODLE test module.

Results. The laboratory workshop consists of 18 simulation laboratory works. The design of the interface of educational simulations is based on an important didactic principle: to be responsible for the educational needs of students. All simulations are animated, interactive, some have game environments in which you can learn how devices work through research. It is shown which design solutions achieve the optimal human-machine interface of educational simulations in the laboratory workshop. The article describes the scenario of organization of independent student's work during studying of the discipline "Physics (selected sections)" based on the developed laboratory workshop using the means of communication LMS MOODLE.

Conclusions. Providing simulation laboratory workshop "Fundamentals of Digital Electronics" in the organization of self-study helps to increase students' motivation to study the course "Physics (selected sections)". The studying of educational games for students' self-education is needed for further research.

Key words: laboratory workshop, digital electronics, simulation, independent work. 